a powerful element in the mining communities until World War I. Mystic elected a socialist mayor in 1904 and repeated the victory in 1906. Madrid elected a socialist mayor in 1911 and Hopkinton in 1912. Colfax and Belle Plaine elected socialists to their town councils in $1911 .^{59}$

In the long run, of course, socialism's triumphs were few and ephemeral. In Iowa as elsewhere they never learned the art of compromise and internal dissension would tear their ranks asunder in those rare places where victory became a surprising reality. They were humanitarians but their vision of Utopia was too complete; they were too rigid to accept the fruits of victory. Wherever they won they began to prey on one another.

But in 1900 the evils in the industrial order that these humanitarians rallied against were real enough. They were good men, able, intelligent, humane, who believed that socialism might have the answer.

${ }^{59}$ Most of the election victories were culled from the Appeal to Reason.

\title{
A PHOTOGRAPHIC RECORD OF THE OLD FEDERAL BUILDING
}

The Summer issue of the Annals of Iowa (Vol. 39, No. 5) contained a brief history of the Old Federal Building, Des Moines, entitled "The Death of Old Fed." Since the publication of that article, a number of excellent photographs have been donated to the State Department of History \& Archives which depict the beauty of this now demolished building. As the Old Federal was of great historical interest and was one of the few remaining examples of its style of architecture a variation of the General Grant style used in most public buildings erected during the first ten years following the Civil War), we feel it worthwhile to here publish selected photographs of this building.

The photographs by Mark A. Knudsen were taken for the National Parks Historic-American Building Survey; they were donated by William J. "Bill” Wagner. The photographs by Joan Muyskens were taken specifically for this Department's files. 


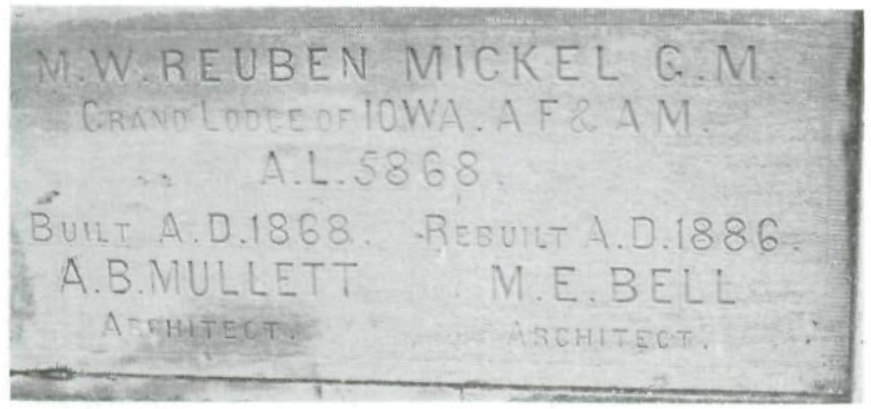

photo by Mark A. Knudsen

Cornerstone of Old Federal Building

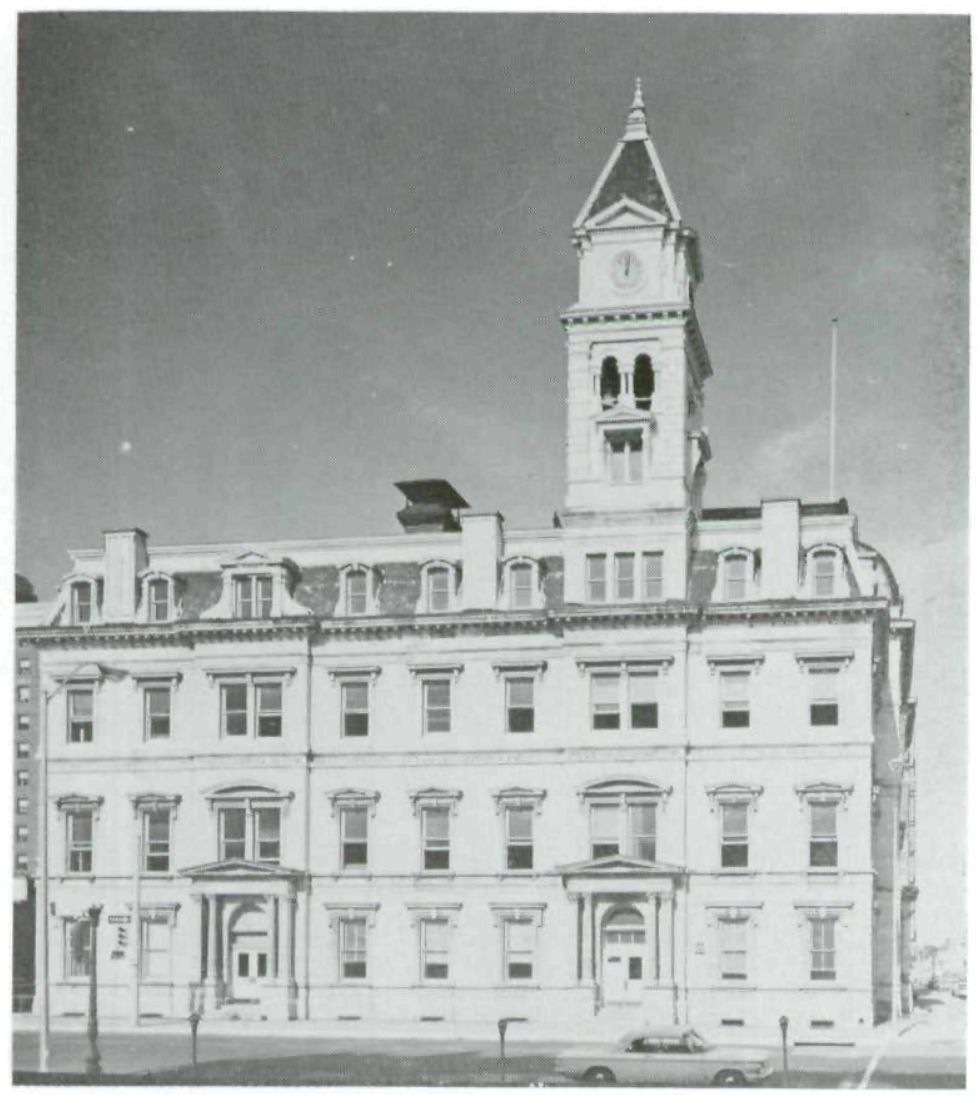

photo by Mark A. Knudsen

West Elevation 


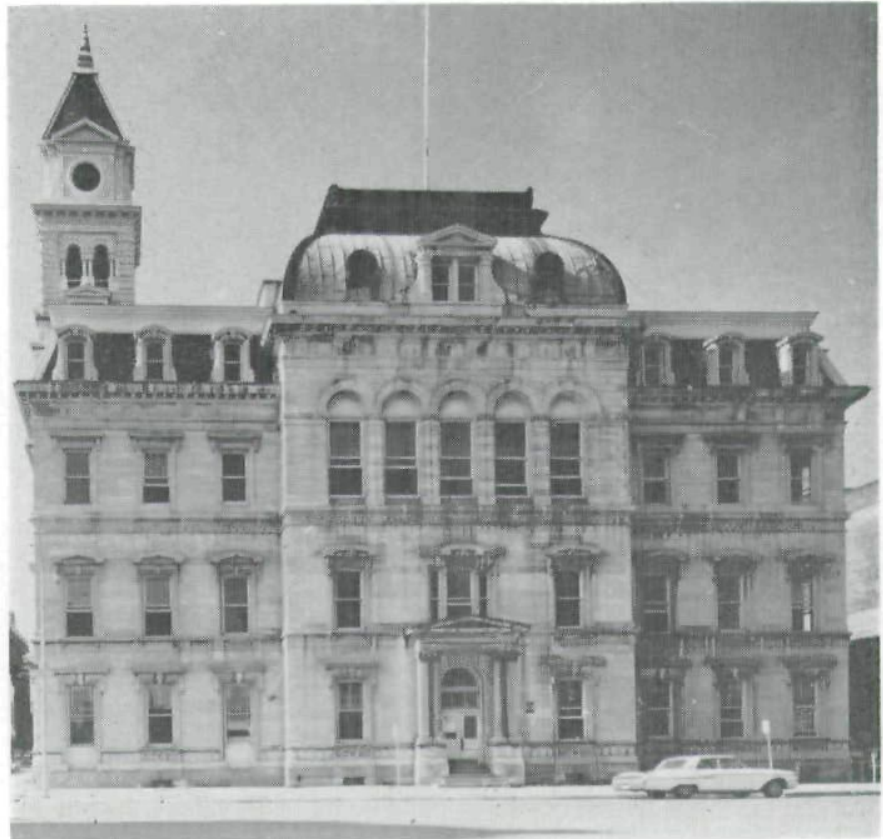

South Elevation

photo by Mark A. Knudsen

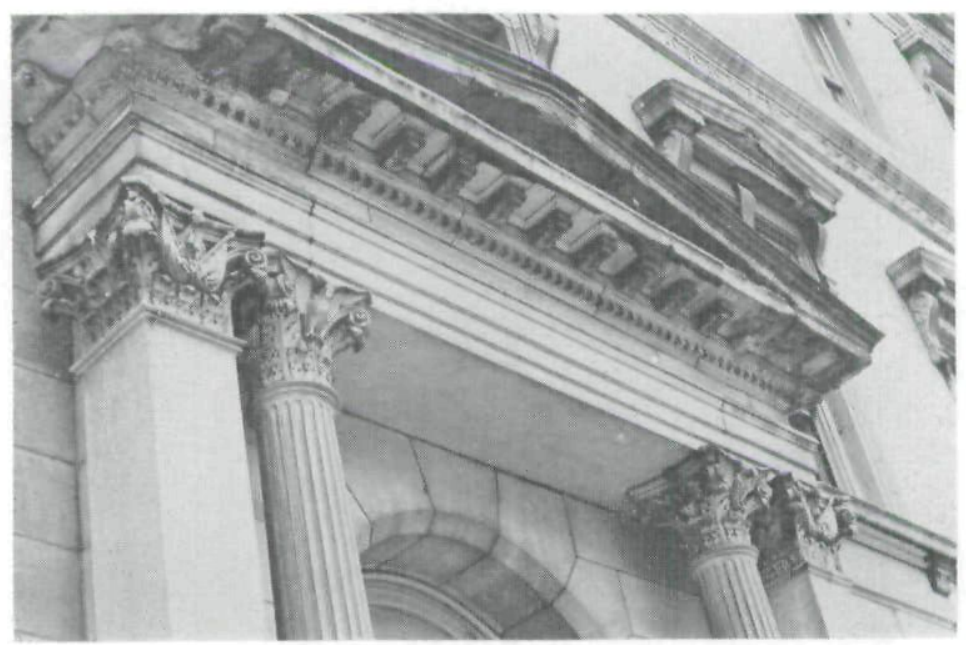

photo by Joan Muyskens 


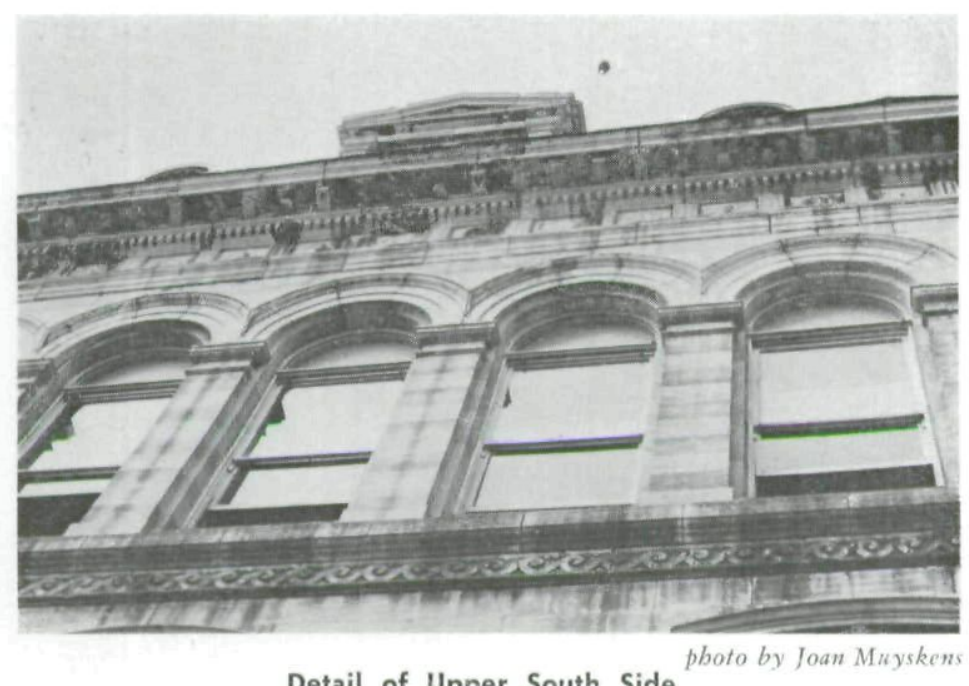

Detail of Upper South Side

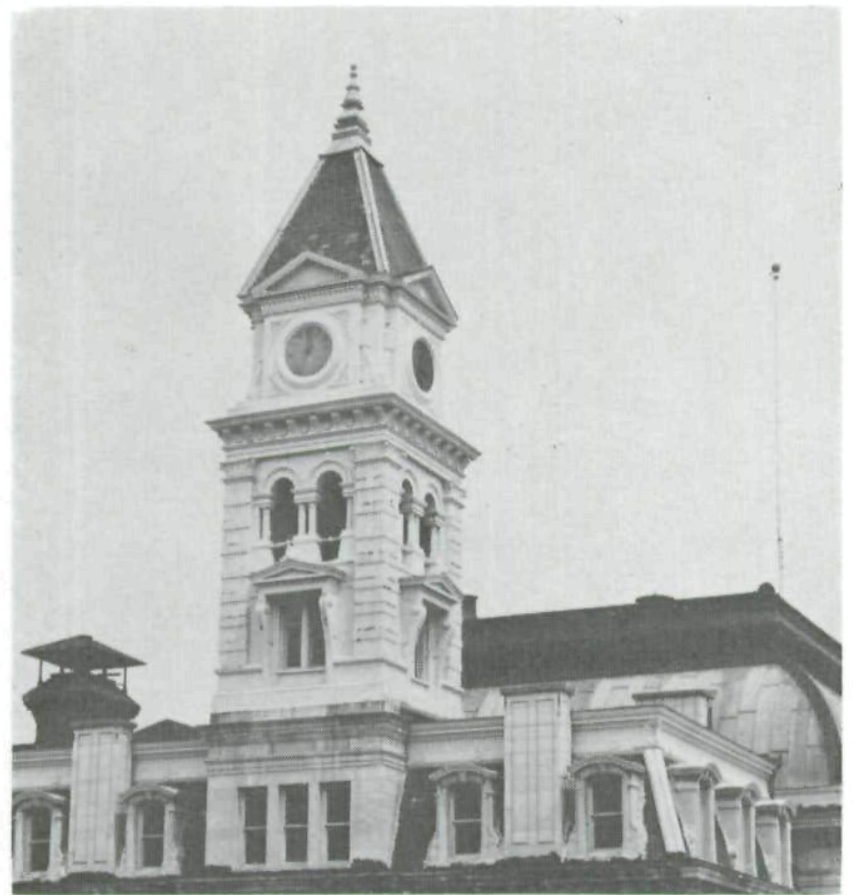

Clock Tower

pboto by Joan Muysken 


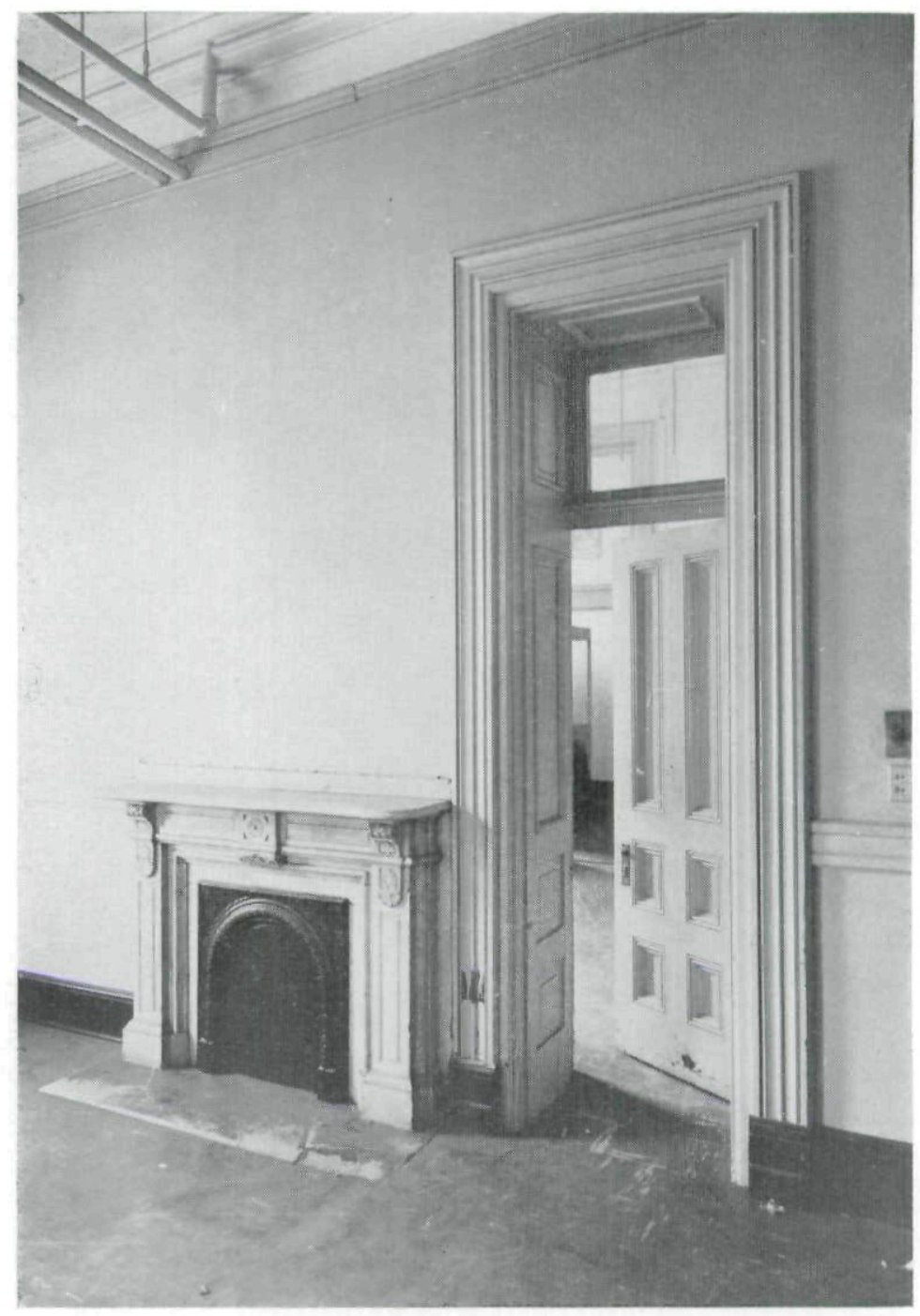

photo by Mark A. Knudsen

First floor looking Southeast. Note the detail of the fireplace, one of 40 originally used to heat the building. 


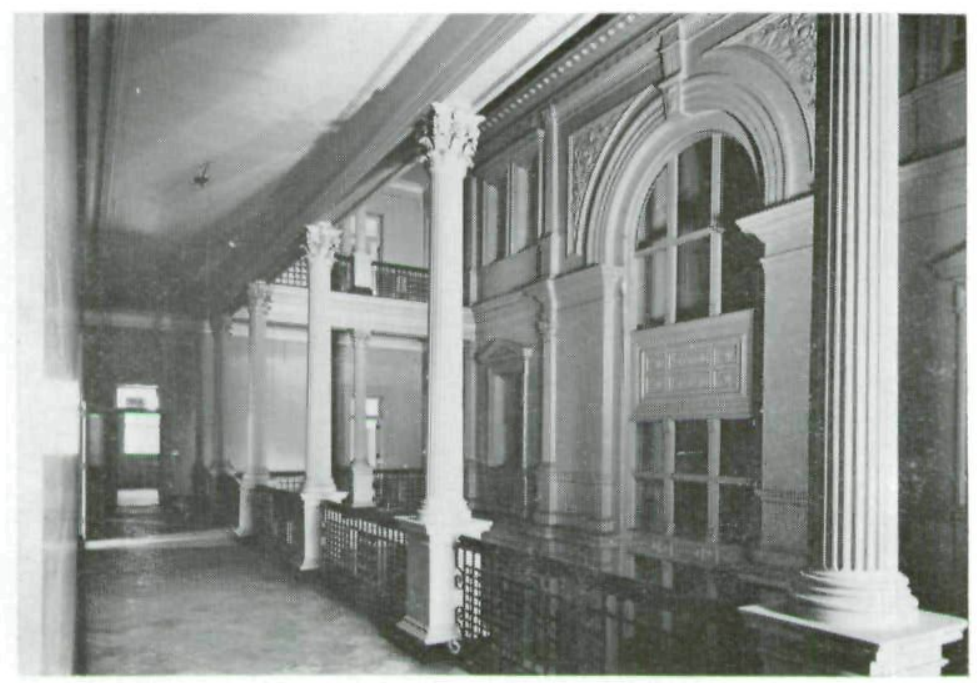

photo by Mark A. Knudsen

Third Floor Courtroom

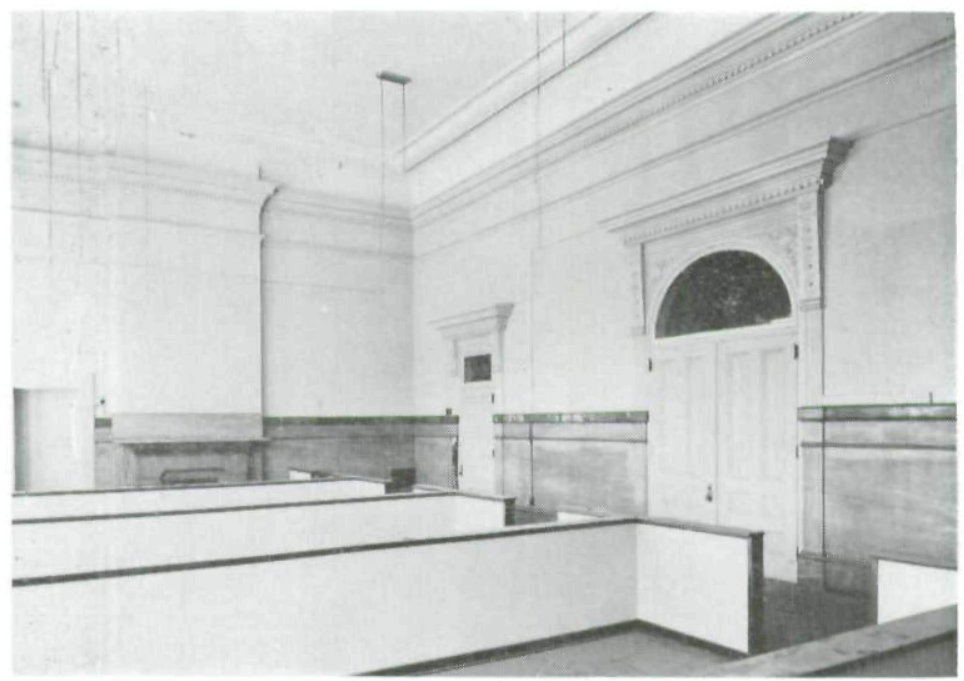

photo by Mark A. Knudsen

Third Floor Light Court 
Copyright of Annals of Iowa is the property of State of Iowa, by \& through the State Historical Society of Iowa and its content may not be copied or emailed to multiple sites or posted to a listserv without the copyright holder's express written permission. However, users may print, download, or email articles for individual use. 